OPEN ACCESS

Edited by:

Aldo Corsetti,

Università di Teramo, Italy

Reviewed by:

Soner Soylu,

Mustafa Kemal University, Turkey

Zhao Chen,

Clemson University, United States

${ }^{*}$ Correspondence:

Anne M. Alvarez

alvarez@hawaii.edu

Specialty section:

This article was submitted to

Food Microbiology,

a section of the journal

Frontiers in Microbiology

Received: 13 July 2017

Accepted: 24 August 2017

Published: 12 September 2017

Citation:

Ahmed FA, Arif M and Alvarez AM

(2017) Antibacterial Effect

of Potassium Tetraborate Tetrahydrate against Soft Rot Disease Agent

Pectobacterium carotovorum

in Tomato. Front. Microbiol. 8:1728.

doi: 10.3389/fmicb.2017.01728

\section{Antibacterial Effect of Potassium Tetraborate Tetrahydrate against Soft Rot Disease Agent Pectobacterium carotovorum in Tomato}

\author{
Firas A. Ahmed, Mohammad Arif and Anne M. Alvarez* \\ Department of Plant and Environmental Protection Sciences, University of Hawaii at Manoa, Honolulu, HI, United States
}

Soft rot caused by Pectobacterium carotovorum is one of most common bacterial diseases occurring in fruits and vegetables worldwide, yet consumer-acceptable options for post-harvest disease management are still insufficient. We evaluated the effect of potassium tetraborate tetrahydrate $\left(\mathrm{B}_{4} \mathrm{~K}_{2} \mathrm{O}_{7} .4 \mathrm{H}_{2} \mathrm{O}\right)$ (PTB) on the growth of $P$. carotovorum using strain BA17 as a representative of high virulence. Complete inhibition of bacterial growth was achieved by treatment with PTB at $100 \mathrm{mM}$ both at $\mathrm{pH} 9.2$ and after adjustment to $\mathrm{pH}$ 7.0. Bactericidal activity was quantified and validated by counting fluorescently labeled live and dead bacterial cells using flow cytometry, and reconfirmed using GPCR with high-affinity photoreactive DNA binding dye propidium monoazide (PMA). The results of flow cytometry, qPCR, and culturing confirmed that bacterial cells were killed following exposure to PTB at $100 \mathrm{mM}$. Bacterial cell membranes were damaged following a 5-min treatment and extrusion of cytoplasmic material from bacterial cells was observed using electronic transmission microscopy. Soft rot incidence on inoculated tomato fruit was significantly reduced by dipping infected fruits in PTB at $100 \mathrm{mM}$ for 5 min and no lesions developed following a 10-min treatment. PTB does not pose a hazard to human health and is an effective alternative to other bactericides and antibiotics for controlling soft rot disease of tomato caused by $P$. carotovorum.

Keywords: Pectobacterium carotovorum, post-harvest disease, tomato, PMA-qPCR cell viability, flow cytometry

\section{INTRODUCTION}

Tomatoes are an important economic crop worldwide and soft rot disease caused by Pectobacterium carotovorum leads to significant post-harvest losses. Soft rot is a predominant progressive decay characterized by tissue maceration, such that the entire fruit is damaged (Bartz and Wei, 2002; Gardan et al., 2003; Charkowski, 2007). Bacterial infections occur in the field, transit, packing, and/or during storage. Quantitative losses caused by soft rot are greater than any other bacterial disease (Bhat et al., 2010). The bacteria are not able to penetrate the surface of tissue directly but rather enter through wounds and natural openings. The bacteria then multiply in the intercellular spaces, where they produce pectolytic enzymes and degrade cell middle lamellae leading to softening of infected tissue (Yang et al., 1992). Currently, there are few effective ways to decontaminate infected tomato fruit that do not pose concerns to human health; thus, 
disease management essentially depends on cultural practices such as avoiding over-irrigation, maintaining proper harvesting, handling and packing practices, cleaning and disinfestations of harvesting equipment, and use proper storage conditions (Gnanamanickam, 2006; Jones et al., 2014).

Recent studies have shown the efficiency of inorganic salts, such as aluminum chloride, sodium thiosulfate, and sodium benzoate to control post-harvest diseases such as soft rot of potato (Yaganza et al., 2014), gray mold of grapevines and tomato (Jeandet et al., 2000; Wu et al., 2015), decay of melons (Aharoni et al., 1997), and citrus green mold (Smilanick et al., 1999). Potassium tetraborate tetrahydrate $\left(\mathrm{B}_{4} \mathrm{~K}_{2} \mathrm{O}_{7} .4 \mathrm{H}_{2} \mathrm{O}\right)(\mathrm{PTB})$ is one of the inorganic salts used for preservation wood worldwide (Freeman et al., 2009). Some studies demonstrated the effectiveness of PTB application to control common postharvest fungal diseases, such as gray mold caused by Botrytis cinerea in table grapes (Qin et al., 2010), anthracnose caused by Colletotrichum gloeosporioides in mango (Shi et al., 2011, 2012). PTB has been used in industry and agriculture as safe compounds for control of many fungi and insects (Qin et al., 2007). However, there is no documentation on the use of PTB to control post-harvest diseases caused by bacteria. Flow cytometry is a rapid sensitive method for quantifying of live and dead cells in suspension (O'Brien-Simpson et al., 2016; Massicotte et al., 2017). Propidium monoazide (PMA) is high-affinity photoreactive DNA binding dye that has recently been used to distinguish intact from membrane- damage of bacterial cells and other microorganisms. PMA only penetrates into dead bacterial cells with damaged membrane but not live cells with the intact membrane (Nocker et al., 2006). PMA Combined with qPCR was successfully used to quantify the viability of bacterial cells (Bae and Wuertz, 2009; Kim and Ko, 2012). The objective of this study was to investigate the effectiveness of PTB for reducing soft rot of tomato caused by P. carotovorum.

\section{MATERIALS AND METHODS}

\section{Bacterial Strain}

The bacterial strain used for these studies was $P$. carotovorum BA17, which was the most virulent strain isolated in Hawaii. Pathogenicity was confirmed on three types of tomato including, common market, cherry and grape tomato. Several bacteriological tests including oxidation/fermentation (OF), production of catalase, degradation of sodium polypectate, $\mathrm{KOH}$ test and hydrolysis of esculin and starch were conducted on each strain. Presumptive identifications were confirmed by $16 \mathrm{~S}$ rDNA sequence analysis (Ahmed et al., 2017). All strains were maintained in freezers at $-80^{\circ} \mathrm{C}$ for further testing.

\section{Determination of Antibacterial Activity and Minimum Bactericidal Concentration of PTB In Vitro Conditions}

The antibacterial activity of PTB (Sigma-Aldrich, St. Louis, MO, United States) was assessed for P. carotovorum using a paper disk diffusion method (Jorgensen and Turnidge, 2015). One $\mathrm{ml}$ of an overnight broth culture of bacteria was diluted to obtain an inoculum of $10^{8} \mathrm{CFU} / \mathrm{ml}$ using a spectrophotometer $(600 \mathrm{~nm})$. A $50 \mu \mathrm{l}$ aliquot was spread evenly on solid agar plates containing Luria media using sterile swabs. Sterile $13-\mathrm{mm}$ paper disks were saturated with PTB in increasing concentrations ranging from 10 to $120 \mathrm{mM}$. The first tests were run at $\mathrm{pH} 9.2$ (with no $\mathrm{pH}$ adjustment) and a second set was run after adjustment to $\mathrm{pH} 7.0$ following neutralization with $0.1 \mathrm{~N} \mathrm{HCl}$. Plates were divided into four quarters, and one paper disk was placed in each quadrant. Paper disks saturated with sterile water were used as controls. Plates were incubated at $28^{\circ} \mathrm{C}$ for $24 \mathrm{~h}$, and the inhibition zone area was measured. For determination of minimum bactericidal concentration (MBC), tubes containing Luria broth and PTB at concentrations ranging from 10 to $100 \mathrm{mM}$ were inoculated with $20 \mu \mathrm{l}$ aliquots of a $P$. carotovorum suspension that contained $10^{8} \mathrm{CFU} / \mathrm{ml}$. Tubes were placed in the incubator shaker for $16 \mathrm{~h}$ at $28^{\circ} \mathrm{C}, 140 \mathrm{rpm}$. Two controls were used: (i) inoculated Luria broth lacking PTB, and (ii) non-inoculated broth. After incubation, Aliquots $(20 \mu \mathrm{l})$ of resuspended media were spotted onto Luria agar plates divided into four quadrants. Plates were incubated at $28^{\circ} \mathrm{C}$ for $24 \mathrm{~h}$. Plates were checked daily over the next 7 days to determine whether growth occurred. The lowest concentration of PTB that killed the P. carotovorum was recorded as MBC. The experiments were performed with four replicates and repeated three times. To confirm that the effect was bactericidal and not bacteriostatic, the experiment above was repeated except that broth cultures were centrifuged, the pellet containing bacterial cells were washed three times with sterile saline, and resuspended in Luria broth lacking PTB. Aliquots were again spotted onto Luria agar plates and incubated as above. This experiment was repeated twice.

\section{Validation of Antimicrobial Activity of PTB Using Flow Cytometry Analyses}

Flow cytometry was performed to validate the bactericidal activity of PTB using viability dyes, Syto9 (membrane permeable) and propidium iodide (PI, membrane impermeable) (O'BrienSimpson et al., 2016). Control samples of live (measured by colony plate counts) and dead cells (killed by $70 \%$ isopropanol) were first established as controls for flow cytometry runs before determining the numbers of live and dead cells in samples treated with PTB. Liquid NB 24 h old cultures of $P$. carotovorum were treated with different concentrations of PTB (50-, 60, 70-, 80-, 90-, and $100-\mathrm{mM}$ ) for $16 \mathrm{~h}$ at $28^{\circ} \mathrm{C}$ with shaking at $140 \mathrm{rpm}$. The bacterial suspensions were centrifuged, and the pellet was washed twice with $0.85 \% \mathrm{NaCl}$. Bacterial cells were stained with the LIVE/DEAD BacLight kit components of Syto9 and propidium iodide (Thermo Fisher, Grand Island, NY, United States) following the protocol provided by the manufacturer. Samples were analyzed with a Beckman-Coulter EPICS XL flow cytometry instrument (FlowJo, Ashland, OR, United States) using $15 \mathrm{~mW} 488 \mathrm{~nm}$ excitation (argon ion laser). The fluorescence signals from the Syto9-stained cells (LIVE) were collected (green $525 \mathrm{~nm}$ BP filter), along with PI-stained cells (DEAD) (red $610 \mathrm{~nm} \mathrm{BP}$ filter). Forward and side light scatter signals were measured. Two-parameter histograms of log PI 
fluorescence vs. log Syto9 fluorescence were analyzed in FlowJo software, which is designed to distinguish live and dead cells and to calculate the percentage of each cell type. Each experiment was conducted with four replicates, and the test was repeated three times.

\section{Validation of Antimicrobial Activity of PTB Using qPCR-Based Method with Propidium Monoazide (PMA) to Distinguish Viable from Non-viable Bacteria Cells}

A PMA assay was conducted using the BLU-V Viability PMA kit (Qiagen, Valencia, CA, United States) following the manufacturer's instructions. A suspension of $P$. carotovorum containing $10^{8} \mathrm{CFU} / \mathrm{ml}$ was treated with $100 \mathrm{mM}$ PTB in nutrient broth for $16 \mathrm{~h}$ at $28^{\circ} \mathrm{C}$ with shaking $140 \mathrm{rpm}$. Four control samples were prepared: live and dead bacterial cells each with and without PMA. As a control, bacterial cells were killed by heating for $10 \mathrm{~min}$ at $70^{\circ} \mathrm{C}$ in a thermomixer. Treated and non-treated bacterial suspensions were centrifuged for $5 \mathrm{~min}$ at 13,000 $\times g$. A $10 \mu \mathrm{l}$ volume of $2.5 \mathrm{mM}$ of PMA reagent was added to the cell pellet containing $500 \mu \mathrm{l}$ of EB buffer. After incubation for $10 \mathrm{~min}$ at room temperature in the dark, samples were exposed to light for 20 min using a 650-W halogen light source (Kobayashi et al., 2009). The samples were laid on the ice at a 45 angle and $20 \mathrm{~cm}$ in front of the light source. After photoactivation of PMA, the bacterial suspension was centrifuged at 7,600 rpm for $10 \mathrm{~min}$, and DNA was extracted.

\section{DNA Extraction and SYBR Green Real-time qPCR}

A DNeasy Blood \& Tissue Kit (Qiagen) was used to isolate DNA from PMA-treated and non-treated $P$. carotovorum cultures following the manufacturer's protocol. Primer set PECF (5'-GTGCAAGCGTTAATCGGAATG-3 $\left.{ }^{\prime}\right)$ and PEC-R (5' CTCTACAAGACTCTAGCCTGTCAGT TT-3') targeting the 16S rRNA gene (Pritchard et al., 2013) was used for SYBR Green qPCR-based specific detection of $P$. carotovorum; primers were synthesized by Integrated DNA Technologies (IDT, Coralville, IA, United States). SYBR Green qPCR assays were performed in a $25 \mu \mathrm{l}$ reaction mixture containing $12.5 \mu \mathrm{l}$ SsoAdvance Universal Supermix (Bio-Rad, Hercules, CA, United States), $8.5 \mu \mathrm{l}$ of ultrapure water (Thermo Fisher Scientific, Grand Island, NY, United States), and $0.2 \mu \mathrm{M}$ of each forward and reverse primer. SYBR Green qPCR conditions were $30 \mathrm{~s}$ at $95^{\circ} \mathrm{C}$ followed by 30 cycles of $10 \mathrm{~s}$ at $95^{\circ} \mathrm{C}$ and $30 \mathrm{~s}$ at $60^{\circ} \mathrm{C}$ using CFX96 Real-Time PCR Detection System (Bio-Rad). Three replicates were used for each reaction and water was used as a non-template control. Cycle threshold was set manually, and Bio-Rad CFX Manager 3.1 software was used to analyze the data.

\section{Transmission Electron Microscopy (TEM)}

The possible damage to bacterial membranes treated with and without PTB was assessed using TEM following the method of Al-Adham et al. (2000) with slight modification. An overnight culture P. carotovorum (BA17) was grown on NB supplemented with or without $100 \mathrm{mM}$ PTB for $16 \mathrm{~h}$ at $28^{\circ} \mathrm{C}$ with shaking $140 \mathrm{rpm}$. One-ml aliquots were centrifuged at $4000 \times g$ for $10 \mathrm{~min}$ at room temperature and washed two times with sterile distilled water. The pelleted cells were fixed with $4 \%$ glutaraldehyde in $0.1 \mathrm{M}$ sodium cacodylate buffer, $\mathrm{pH} 7.2$, held at room temperature overnight and washed in $0.1 \mathrm{M}$ cacodylate buffer $2 \mathrm{x}$ for $10 \mathrm{~min}$, followed by post-fixation with $1 \% \mathrm{OsO}_{4}$ in $0.1 \mathrm{M}$ cacodylate buffer for $1 \mathrm{~h}$. Cells were dehydrated in a graded ethanol series $(30,50,70,85,95$, and 100\%), substituted with propylene oxide, and embedded in LX112 epoxy resin and placed in a $60^{\circ} \mathrm{C}$ oven for $24 \mathrm{~h}$ to polymerize the resin. Ultrathin $(60-80 \mathrm{~nm})$ sections made on a resin-fixed pellet using RMC PowerTome Ultramicrotome and double stained with uranyl acetate and lead citrate. Sections were examined utilizing a Hitachi HT7700 TEM (Hitachi, Tokyo, Japan) at $100 \mathrm{kV}$ and photographed with an AMT XR-41B 2kx and 2k CCD camera.

\section{In Vivo Effects of PTB on Soft Rot Disease Symptoms on Tomato Fruit} Protective Action of PTB

A method using potassium tetraborate tetrahydrate was used to assess the efficacy of PTB for protection the tomato fruit from soft rot caused by P. carotovorum. Tomato fruits that were uniform in size and color, free from wounds and rot were selected. The fruits were washed with tap water; surface sterilized by dipping in $1 \%$ sodium hypochlorite solution for $10 \mathrm{~min}$, rinsed by immersing in two changes of sterile distilled water, and dried in ambient air. A wound $1 \mathrm{~mm}$ diameter in $4 \mathrm{~mm}$ deep was made on each fruit using a pipette tip. Wounded fruits were immersed for $10 \mathrm{~min}$ in the different PTB concentrations (0-, 90-, 100-, and 120- mM) for 1-, 2-, 5- and 10- min, and then dried in ambient air. Each wound was inoculated with a $10-\mu \mathrm{l}$ aliquot containing $1 \times 10^{8} \mathrm{CFU} / \mathrm{ml}$ of $P$. carotovorum (Chen and $\mathrm{Zhu}, 2011$ ). Bacterial suspensions were prepared from $24 \mathrm{~h}$-old cultures grown on Luria agar (Difco, Sparks, MD, United States). Fruits were placed onto wet paper towels in a plastic container and incubated for 3 days at $24^{\circ} \mathrm{C}$. Disease severity was assessed by measuring lesion diameter on each fruit. Each treatment contains five fruits. Lesion diameter was the mean of the five fruits in each replicate. The experiment was repeated twice.

\section{Curative Action of PTB}

A curative assay was conducted using the procedures used for the protective assay except that the wounded fruit were immersed in the borate solution for $12 \mathrm{~h}$ after inoculation (Yaganza et al., 2014). Each treatment was replicated by five fruits and the test was repeated twice.

\section{Statistical Analysis}

The experiments were set up as complete randomized design (CRD) with four replications. Data were analyzed using SAS 9.2 V (SAS Institute, Inc., Cary, NC, United States) and means were compared by Duncan's multiple range tests. Differences at $p<0.05$ were considered significant. The experiments were repeated two to three times. 


\section{RESULTS}

\section{Molecular Identification}

A PCR product was obtained for all bacterial strains with expected size $1.4 \mathrm{~kb}$. An NCBI BLAST that sequences of BA12 and BA15 were matched $>98 \%$ with Pectobacterium spp. For BA17, the similarity was $\geq 100 \%$ to P. carotovorum (Ahmed et al., 2017).

\section{Antimicrobial Activity of PTB at pH 7.0 and $\mathrm{pH} 9.2$}

Maximum inhibition of $P$. carotovorum occurred at $100 \mathrm{mM}$. The inhibition zone increased with the increase of PTB concentrations $(p<0.05)$. A $100 \mathrm{mM}$, the inhibition zone was $22 \mathrm{~mm}$ compared with control (water only) $0.00 \mathrm{~mm}$ regardless of the $\mathrm{pH}$ (Figures 1, 2). There was not different in inhibition zone at 100 and $120 \mathrm{mM}$ PTB $(p>0.05)$. These results confirm that while the high $\mathrm{pH}(\mathrm{pH} 9.5)$ accounts for some of the bactericidal activity of PTB, high $\mathrm{pH}$ is not the sole explanation for its bactericidal action.

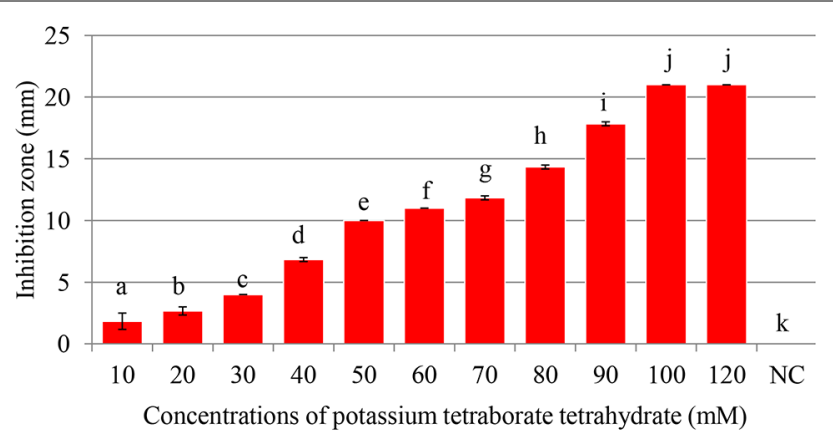

FIGURE 1 | Antibacterial activity of of potassium tetraborate tetrahydrate (PTB) at pH 9.2. Maximum inhibition of Pectobacterium carotovorum occurred at $100 \mathrm{mM}$. Vertical bars show mean values and standard error ( $\pm \mathrm{SE}$ ). Means with different letters are statistically different according to Duncan's multiple range test $(p<0.05)$.

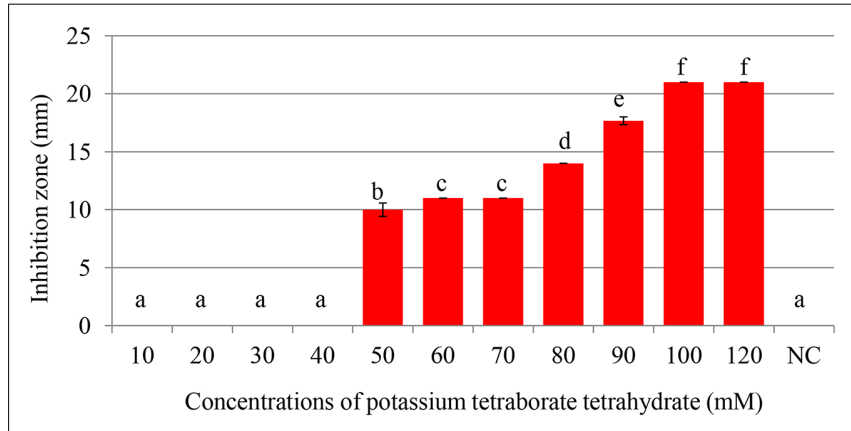

FIGURE 2 | Inhibition of Pectobacterium carotovorum by increasing concentrations of potassium tetraborate tetrahydrate (PTB) at $\mathrm{pH} 7.0$. Bacterial growth was partially inhibited at $50 \mathrm{mM}$; maximum inhibition zones were produced at $100 \mathrm{mM}$ PTB. Vertical bars show mean values and standard error $( \pm S E)$. Means with different letters are statistically different according to Duncan's multiple range test $(p<0.05)$.

\section{Minimum Bactericidal Concentration (MBC)}

The number of colonies that grew on test plates decreased as the PTB concentrations in the medium increased (Figure 3). No bacterial colonies appeared on plates containing $100 \mathrm{mM}$ РTB after $24 \mathrm{~h}$ incubation at $28^{\circ} \mathrm{C}$, and there was no regrowth on these plates after 7 days. Furthermore, after washing pelleted cells three times before plating onto Luria agar, no colonies grew from tubes containing $100 \mathrm{mM}$ potassium tetraborate tetrahydrate, and this was established as the MBC.

\section{Flow Cytometric Analysis of Bactericidal Activity of PTB}

Live cells with intact cell membranes were distinguished from dead isopropanol-treated bacterial cells as shown on flow cytometry dot blots and histograms (Figure 4). Live cells of P. carotovorum stained with Syto9 dye and clustered in the lower gate ( $98 \%$ of the data points) whereas $2 \%$ of the cells stained with propidium iodide and clustered in the upper gate (Figure $4 \mathrm{~A}$ ). Conversely, with the dead-cell-control, $97 \%$ of the data points were in the upper gate whereas $3 \%$ of the data points were in the lower gate (Figure 4B). Following treatment with $50 \mathrm{mM} \mathrm{PTB}$ $56 \%$ of the cells were dead and $44 \%$ were live (Figure $4 \mathrm{C}$ ). The percentage of dead cells in the upper gate continued to increase as the PTB concentrations increased (Figures $4 \mathrm{D}-\mathrm{H}$ ). The nontreated cells stained with Syto9 dye and 95\% clustered in the lower gate and gave a histogram similar to the live cell-control.

\section{Real-time qPCR with PMA Treatment for Analysis of Bactericidal Activity of PTB} Quantitative PCR was performed as an efficient additional method for confirming bactericidal activity of PTB at $100 \mathrm{mM}$.

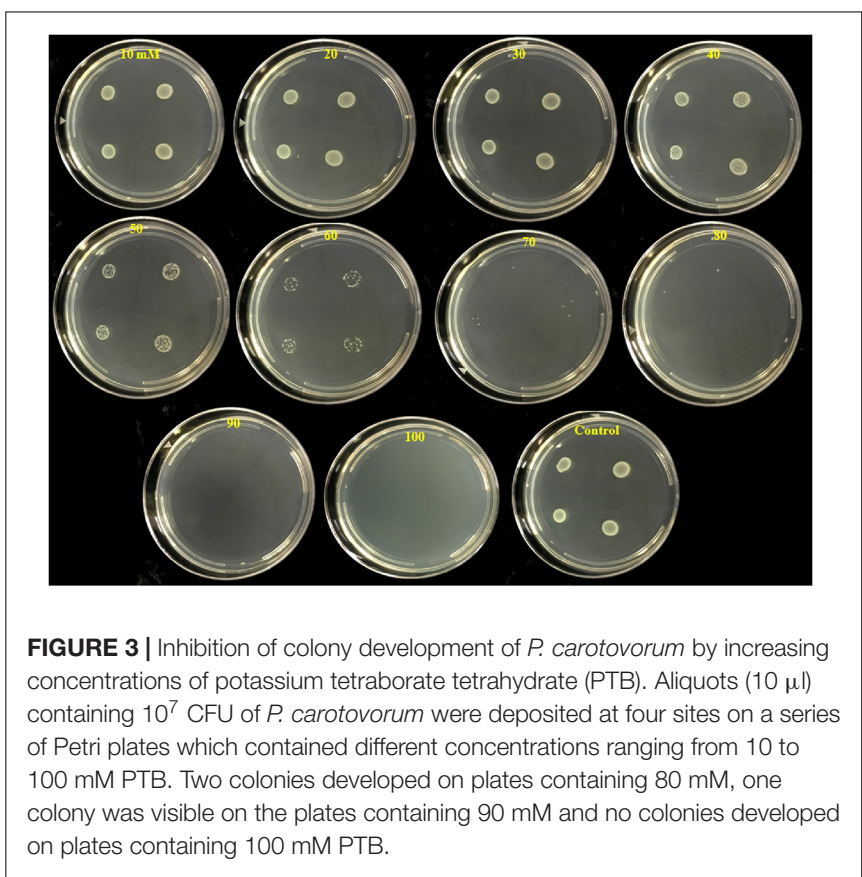



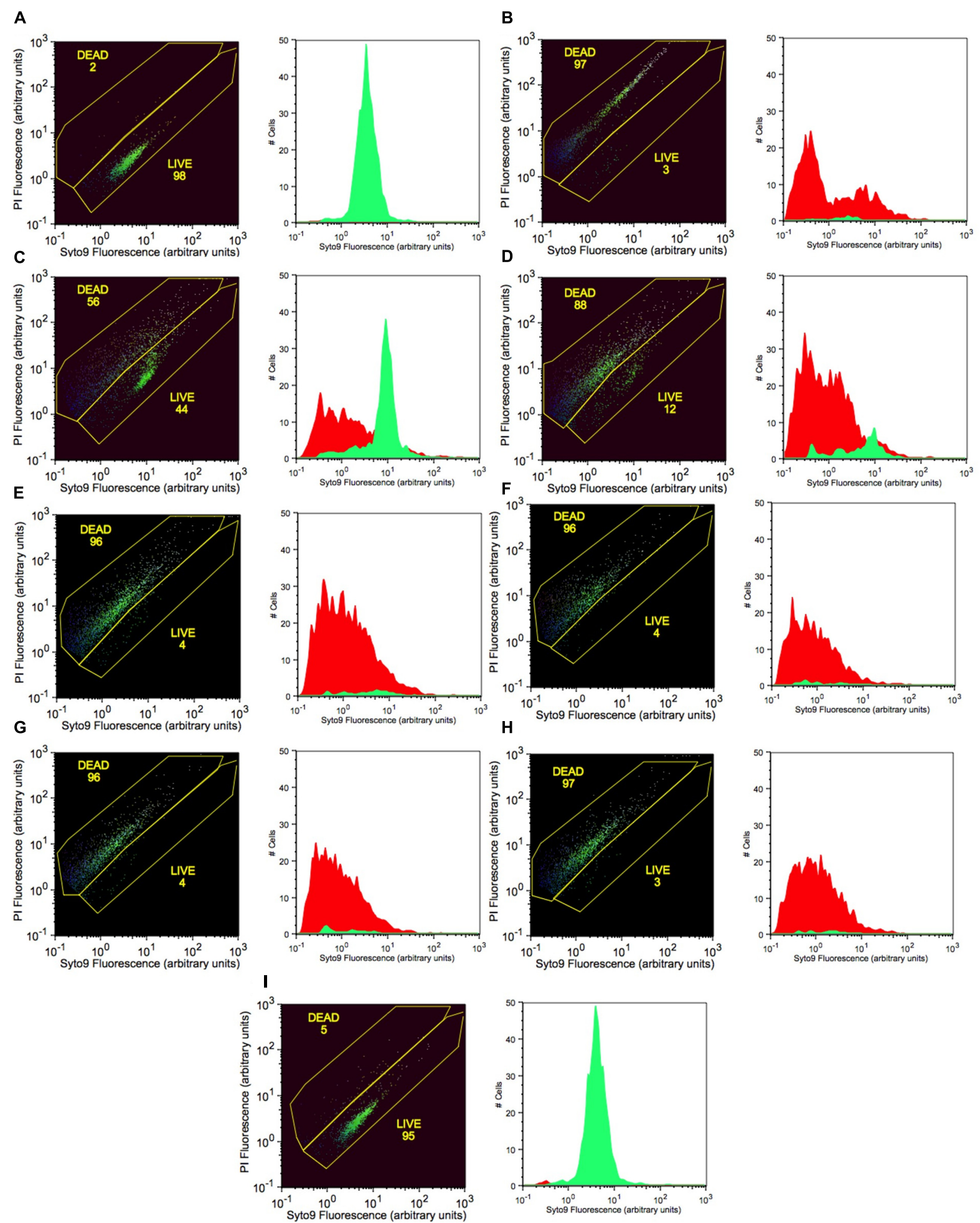

FIGURE 4 | Increasing concentrations of potassium tetraborate tetrahydrate (PTB) increases bacterial membrane permeability to propidium iodide as shown by flow cytometry with Syto9 and PI staining. (A) live cells (non-treated; calibration standard); (B) dead cells (killed with 70\% isopropanol; calibration standard). Bacterial cells treated with PTB at increasing millimolar concentrations (C) 50; (D) 60; (E) 70; (F) 80; (G) 90; (H) 100; (I) non-treated bacteria (control). The X-axis indicates the intensity of Syto9 green fluorescence and the Y-axis indicates the intensity of PI red fluorescence (arbitrary units: a). flow cytometry data are represented as the percentage of live and dead cells (black images) with the fluorescence intensity of Syto9 and PI dyes. Graphs show the images present the cell counts of live (green) and dead (red) cells. 


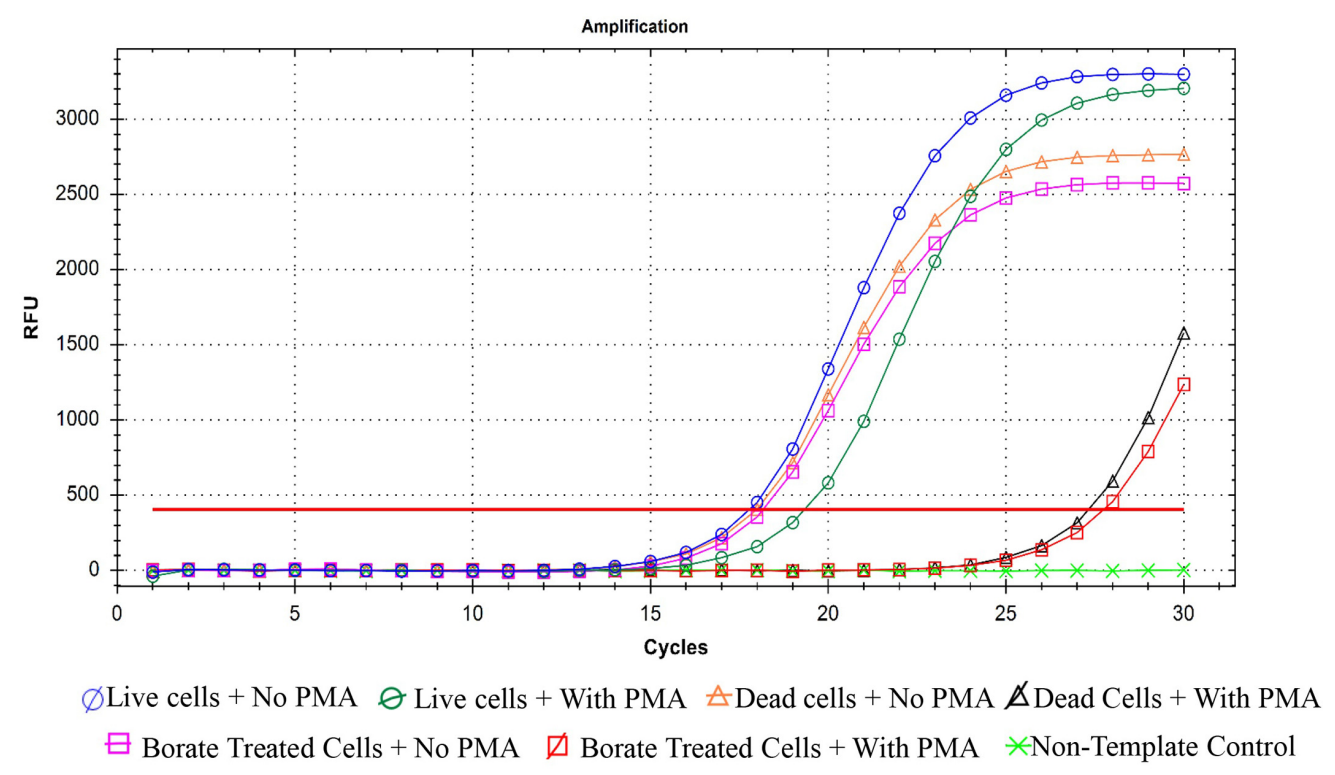

FIGURE 5 | Quantification real-time PCR for P. carotovorum treated with $100 \mathrm{mM}$ potassium tetraborate tetrahydrate (PTB) with and without propidium monoazide (PMA). Data are averages of three separate experiments.

When PMA was absent from bacterial suspensions, qPCR did not distinguish between live and dead cells (Figure 5). Addition of PMA to live bacterial suspensions did not change the Ct values because PMA cannot penetrate membranes of intact cells and had no effect on qPCR. In contrast, when PMA penetrates the membranes of dead bacterial cells, it binds to the DNA and delays amplification, which results in higher $\mathrm{Ct}$ values for the sample. Both the heat- and PTB-treated cells had significantly higher $\mathrm{Ct}$ values (25) than live cells (Ct value, 15). The results obtained by PMA-qPCR coincided with results of flow cytometry and culture plate assays confirming complete kill of bacterial cells with $100 \mathrm{mM}$ PTB.

\section{Effect of PTB on Ultrastructure of Bacterial Cell Analyzed by TEM}

Transmission electronic microscopy was used to visualize morphological changes in $P$. cartovorum cells treated with $100 \mathrm{mM}$ PTB. Cell membranes and cytoplasm were normal showing no noticeable changes in morphological structure in the absence of PTB (Figure 6A). The cells in the untreated control sample of $P$. carotovorum showed intact cell membranes with no deformation or dense cytoplasm. In contrast, bacterial cells grown in nutrient broth supplemented with $100 \mathrm{mM}$ PTB showed distinct signs of deterioration (Figure 6B). The cell membrane was distorted and the cytoplasm exuded from membranes of all the cells observed.

\section{Effect of PTB on Soft Rot Disease of Tomato Fruit}

As a curative treatment, PTB was not effective in reducing soft rot disease $(p>0.05)$. As a preventive treatment, however, PTB applications at 100 and $120 \mathrm{mM}$ completely inhibited lesion development (Figure 7 and Supplementary Figure 1). Fruits dipped into PTB (100 and $120 \mathrm{mM}$ ) for 5 and $10 \mathrm{~min}$ prior to inoculation differend in lesion diameters after 7 days incubation at $23^{\circ} \mathrm{C}$ compared with the control or treatments at lower rates $(p<0.05)$ (Figure 7$)$. These results were consistent with data from MBC, flow cytometry, and qPCR tests. The results indicate that PTB reduced post-harvest soft rot of tomato fruit when fruits were immersed in $100 \mathrm{mM}$ PTB for $5 \mathrm{~min}$. Lesion development was completely inhibited following emersion for $10 \mathrm{~min}$.

\section{DISCUSSION}

Boron is an essential microelement for plant growth and enhancement of fruit quality. In tomato adequate levels of boron are needed to avoid ruptures in the cuticle (Strong and Robert, 2001; Huang and Snapp, 2009). Recently, several studies have demonstrated that PTB can be used as an antifungal compound for control of post-harvest diseases (Qin et al., 2010; Thomidis and Exadaktylou, 2010; Shi et al., 2011, 2012). Other studies provided evidence that boron (Kartal et al., 2004) and PTB (Reeb, 1997) reduced wood damage by termites and fungi. Our study was the first to evaluate the potential of PTB for post-harvest management of soft rot bacterial disease caused by $P$. carotovorum. PTB at $100 \mathrm{mM}$ completely inhibited the growth of $P$. carotovorum, both at its normally high $\mathrm{pH}$ (9.5) and after neutralizing to $\mathrm{pH}$ 7.0. Salt solutions of PTB, potassium carbonate, sodium bicarbonate and sodium carbonate also exhibited antifungal and antibacterial effects independently of pH (Nigro et al., 2006; Qin et al., 2010). Thus, the antibacterial activity of PTB was not due solely to disruption of cell membranes at high $\mathrm{pH}$. The inhibitory effect of boron (as borax and boric 

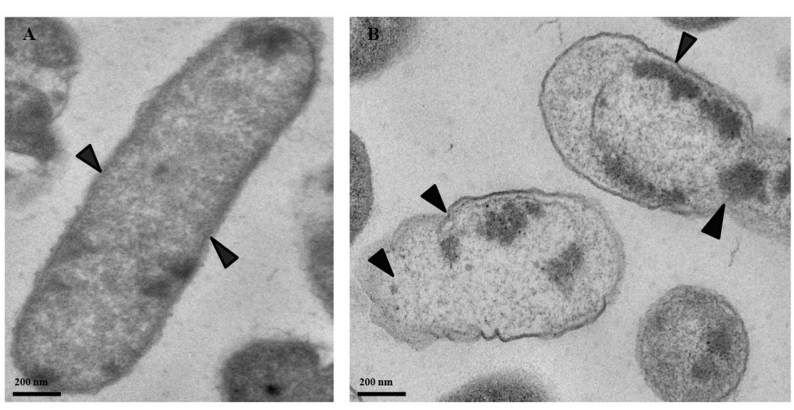

FIGURE 6 | Micrographs of $P$. carotovorum cells examined with transmission electron microscopy (TEM). Bacteria were incubated in nutrient broth medium (NB) without potassium tetraborate tetrahydrate (PTB) (A) or with $100 \mathrm{mM}$ PTB (B). In the absence of borate, the cytoplasm and cell membranes were intact and appeared normal (A; black arrows). Following treatment with $100 \mathrm{mM}$ PTB the cell membranes were degraded, the cytoplasm exuded from damaged areas and cell structure was abnormal (B; black arrows).

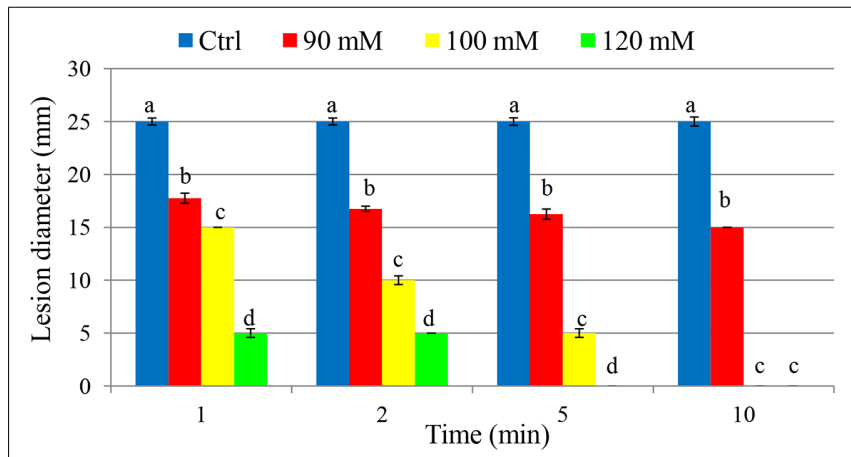

FIGURE 7 | Effect of different potassium tetraborate tetrahydrate (PTB) concentrations at different immersion times on disease severity in tomato fruit following inoculation with $P$. carotovorum. The mean lesion diameter was measured after the treated fruit were stored at $28^{\circ} \mathrm{C}$ for 7 days. Mean values showing different letters are statistically different according to Duncan's multiple range test $(p<0.05)$.

acid) on Escherichia coli, Staphylococcus aureus, Pseudomonas aeruginosa, and Actinetobacter septicus was similar with and without adjusting the $\mathrm{pH}$ value (Yilmaz, 2012).

Several possible mechanisms for the inhibitory effect of borate include binding of borate ions to chemical energy transporters such as ATP, NAD, and NADH leading to impaired protein synthesis, disruption of mitochondria and prevention of cell division (Kim et al., 2003; Reid et al., 2004). Excessively, high salt concentrations disrupt osmoregulatory processes and reduce bacterial growth. High alkalinity can denature protease on the cell surface, change the cytoplasmic pH and disrupt DNA (Gould and Russell, 1991). The water-ionizing capacity and the lipophilicity of the inorganic salts components play an important role in the inhibition of bacterial growth (Yaganza et al., 2009). In addition to water-ionizing capacity, borate salt is possible to possess the feature of hydrophobic nature that would enable the borate salt to interact with lipid components of the bacterial cell membrane.
This interaction leads to dysfunction of the bacteria and results in growth inhibition.

The bactericidal activity of PTB against $P$. carotovorum, was confirmed in our study by flow cytometry using a protocol to assess bactericidal activity (O'Brien-Simpson et al., 2016). Increased PI staining of $P$. carotovorum cells treated with PTB indicates cell membrane disruption resulting in a bactericidal rather than a bacteriostatic effect. The relationship between the borate concentration and the percentage of dead cells was generally linear. The analysis by flow cytometry confirmed results observed in the cultural antibacterial assays. No bacterial colonies developed following a 10-min treatment with PTB at $100 \mathrm{mM}$ or higher. As a further validation, we used quantitative PCR with propidium monoazide, which is a DNA binding agent that can only penetrate cells with severely damaged membranes. PMA has been used in combination with quantitative PCR to differentiate intact from dead bacterial cells (Kobayashi et al., 2009; DesfossésFoucault et al., 2012). The Ct value of borate-treated bacteria was similar to the $\mathrm{Ct}$ value of the dead-cell control, indicating that PTB destroyed cell membranes permitting the PMA to mask DNA and make the maximum primer binding sites unavailable. These results confirm results of the cultural and flow cytometry tests. Transmission electron microscopy (TEM) showed degradation of bacterial cell membranes, exudation of cytoplasm and abnormal cell structure, indicating that treated cells were damaged by PTB. Antifungal action of PTB also was associated with damage to Colletotrichum gloeosporioides (Shi et al., 2011, 2012) and Botrytis cinerea (Qin et al., 2010). Pectobacterium atrosepticum cells were rapidly damaged and killed by exposure to sodium metabisulfite and aluminum chloride salts (Yaganza et al., 2004).

As a preventative treatment, PTB applications showed a significant reduction in the development of soft rot disease of tomato fruit. However, it had no curative action, most likely because bacterial multiplication cannot be arrested once the bacteria enter wounded fruit. PTB is a promising bactericidal agent for controlling soft rot disease caused by $P$. carotovorum and presents low risk to human health (Çelikezen et al., 2014). In addition, application of PTB is inexpensive and can be applied to tomato fruit before shipping to the market.

\section{CONCLUSION}

PTB salt at $100 \mathrm{mM}$ was clearly bactericidal against $P$. carotovorum and its bactericidal activity was confirmed by TEM, flow cytometry and qPCR. Preventive 1-5-min dip applications of potassium tetraborate at $100 \mathrm{mM}$ significantly reduced lesion diameters in fruits inoculated with $P$. carotovorum. No lesions developed following a $10-\mathrm{min}$ dip treatment. PTB can be a safe and cost-effective alternative for preventing soft rot disease in post-harvest tomato fruit.

\section{AUTHOR CONTRIBUTIONS}

FA and AA designed the study, FA performed the experiments and wrote the manuscript, FA and MA conducted qPCR. MA and 
AA revised the manuscript and provided ideas and support for the final submission. All authors reviewed the manuscript.

\section{FUNDING}

This research was supported in part by the Higher Committee for Educational Development in Iraq and the University of Hawaii Foundation Project 120-506-04, Plant Disease Control.

\section{REFERENCES}

Aharoni, Y., Fallik, E., Copel, A., Gil, M., Grinberg, S., and Klein, J. (1997). Sodium bicarbonate reduces postharvest decay development on melons. Postharvest Biol. Technol. 10, 201-206. doi: 10.1016/S0925-5214(97)01412-9

Ahmed, F. A., Sipes, B. S., and Alvarez, A. M. (2017). Postharvest diseases of tomato and natural products for disease management. Afr. J. Agric. Res. 12, 684-691. doi: 10.5897/AJAR2017.12139

Al-Adham, I. S. I., Khalil, E., Al-Hmoud, N. D., Kierans, M., and Collier, P. J. (2000). Microemulsions are membrane-active, antimicrobial, self-preserving systems. J. Appl.Microbiol. 89, 32-39. doi: 10.1046/j.1365-2672.2000.01078.x

Bae, S., and Wuertz, S. (2009). Discrimination of viable and dead fecal Bacteroidales bacteria by quantitative PCR with propidium monoazide. Appl. Environ. Microbiol. 75, 2940-2944. doi: 10.1128/AEM.01333-08

Bartz, J. A., and Wei, C.-I. (2002). "The influence of bacteria," in Postharvest Physiology and Pathology of Vegetables, ed. M. Dekker (Boca Raton, FL: CRC Press), 519-541.

Bhat, K., Masood, S., Bhat, N., Bhat, M. A., Razvi, S., Mir, M., et al. (2010). Current status of post harvest soft rot in vegetables: a review. Asian J. Plant Sci. 9, 200-208. doi: 10.3923/ajps.2010.200.208

Çelikezen, F. Ç, Turkez, H., Togar, B., and Izgi, M. S. (2014). DNA damaging and biochemical effects of potassium tetraborate. EXCLI J. 13, 446-450.

Charkowski, A. (2007). The Soft Rot Erwinia. Plant-Associated Bacteria. Dordrecht: Springer, 423-505.

Chen, Z., and Zhu, C. (2011). Modelling inactivation by aqueous chlorine dioxide of Dothiorella gregaria Sacc. and Fusarium tricinctum (Corda) Sacc. spores inoculated on fresh chestnut kernel. Lett. Appl. Microbiol. 52, 676-684. doi: 10.1111/j.1472-765X.2011.03061.x

Desfossés-Foucault, É, Dussault-Lepage, V., Le Boucher, C., Savard, P., LaPointe, G., and Roy, D. (2012). Assessment of probiotic viability during Cheddar cheese manufacture and ripening using propidium monoazide-PCR quantification. Front. Microbiol. 3:350. doi: 10.3389/fmicb.2012.00350

Freeman, M. H., McIntyre, C. R., and Jackson, D. (2009). A critical and comprehensive review of boron in wood preservation. Proc. Am. Wood Prot. Assoc. 105, 279-294.

Gardan, L., Gouy, C., Christen, R., and Samson, R. (2003). Elevation of three subspecies of Pectobacterium carotovorum to species level: Pectobacterium atrosepticum sp. nov., Pectobacterium betavasculorum sp. nov. and Pectobacterium wasabiae sp. nov. Int. J. Syst. Evol. Microbiol. 53, 381-391. doi: 10.1099/ijs.0.02423-0

Gnanamanickam, S. S. (2006). Plant-Associated Bacteria. Dordrecht: Springer.

Gould, G. W., and Russell, N. J. (1991). Food Preservatives. London: Blackie and Son Ltd.

Huang, J., and Snapp, S. (2009). Potassium and boron nutrition enhance fruit quality in Midwest fresh market tomatoes. Commun. Soil Sci. Plant Anal. 40, 1937-1952. doi: 10.1080/00103620902896811

Jeandet, P., Adrian, M., Breuil, A., Sbaghi, M., Debord, S., Bessis, R., et al. (2000). Chemical induction of phytoalexin synthesis in grapevines: application to the control of gray mold in the vineyard. Acta Hortic. 5, 591-596. doi: 10.17660/ ActaHortic.2000.528.88

Jones, J. B., Zitter, T. A., Momol, T. M., and Miller, S. A. (2014). Compendium of Tomato Diseases and Pests. Saint Paul, MN: American Phytopathological Society.

\section{ACKNOWLEDGMENT}

We thank Brent Sipes for reviewing the paper and Karen Selph for her assistance with flow cytometry.

\section{SUPPLEMENTARY MATERIAL}

The Supplementary Material for this article can be found online at: http://journal.frontiersin.org/article/10.3389/fmicb. 2017.01728/full\#supplementary-material

Jorgensen, J. H., and Turnidge, J. D. (2015). "Susceptibility test methods: dilution and disk diffusion methods," in Manual of Clinical Microbiology, 11th Edn, eds J. Jorgensen, M. Pfaller, K. Carroll, G. Funke, M. Landry, S. Richter, et al. (Washington, DC: American Society of Microbiology Press), 1253-1273.

Kartal, S., Yoshimura, T., and Imamura, Y. (2004). Decay and termite resistance of boron-treated and chemically modified wood by in situ co-polymerization of allyl glycidyl ether (AGE) with methyl methacrylate (MMA). Int. Biodeterior. Biodegradation 53, 111-117. doi: 10.1016/j.ibiod.2003.09.00

Kim, D. H., Marbois, B. N., Faull, K. F., and Eckhert, C. D. (2003). Esterification of borate with NAD+ and NADH as studied by electrospray ionization mass spectrometry and 11B NMR spectroscopy. J. Mass Spectrom. 38, 632-640. doi: $10.1002 / j m s .476$

Kim, S., and Ko, G. (2012). Using propidium monoazide to distinguish between viable and nonviable bacteria, MS2 and murine norovirus. Lett. Appl. Microbiol. 55, 182-188. doi: 10.1111/j.1472-765X.2012.03276.x

Kobayashi, H., Oethinger, M., Tuohy, M. J., Hall, G. S., and Bauer, T. W. (2009). Improving clinical significance of PCR: use of propidium monoazide to distinguish viable from dead Staphylococcus aureus and Staphylococcus epidermidis. J. Orthop. Res. 27, 1243-1247. doi: 10.1002/jor.20872

Massicotte, R., Mafu, A. A., Ahmad, D., Deshaies, F., Pichette, G., and Belhumeur, P. (2017). Comparison between flow cytometry and traditional culture methods for efficacy assessment of six disinfectant agents against nosocomial bacterial species. Front. Microbiol. 8:112. doi: 10.3389/fmicb.2017. 00112

Nigro, F., Schena, L., Ligorio, A., Pentimone, I., Ippolito, A., and Salerno, M. G. (2006). Control of table grape storage rots by pre-harvest applications of salts. Postharvest Biol. Technol. 42, 142-149. doi: 10.1016/j.postharvbio.2006. 06.005

Nocker, A., Cheung, C.-Y., and Camper, A. K. (2006). Comparison of propidium monoazide with ethidium monoazide for differentiation of live vs. dead bacteria by selective removal of DNA from dead cells. J. Microbiol. Methods 67, 310-320. doi: 10.1016/j.mimet.2006.04.015

O’Brien-Simpson, N. M., Pantarat, N., Attard, T. J., Walsh, K. A., and Reynolds, E. C. (2016). A rapid and quantitative flow cytometry method for the analysis of membrane disruptive antimicrobial activity. PLOS ONE 11:e0151694. doi: 10.1371/journal.pone.0151694

Pritchard, L., Humphris, S., Saddler, G. S., Parkinson, N. M., Bertrand, V., Elphinstone, J. G., et al. (2013). Detection of phytopathogens of the genus Dickeya using a PCR primer prediction pipeline for draft bacterial genome sequences. Plant Pathol. 62, 587-596. doi: 10.1111/j.1365-3059.2012. 02678.x

Qin, G., Tian, S., Chan, Z., and Li, B. (2007). Crucial role of antioxidant proteins and hydrolytic enzymes in pathogenicity of Penicillium expansum analysis based on proteomics approach. Mol. Cell. Proteomics 6, 425-438. doi: 10.1074/ mcp.M600179-MCP200

Qin, G., Zong, Y., Chen, Q., Hua, D., and Tian, S. (2010). Inhibitory effect of boron against Botrytis cinerea on table grapes and its possible mechanisms of action. Int. J. Food Microbiol. 138, 145-150. doi: 10.1016/j.ijfoodmicro.2009. 12.018

Reeb, J. (1997). Wood-Destroying Organisms \& Wood Preservatives. Cooperative Extension Service, FOR-54. Lexington, KY: University of Kentucky, College of Agriculture. 
Reid, R. J., Hayes, J. E., Post, A., Stangoulis, J. C. R., and Graham, R. D. (2004). A critical analysis of the causes of boron toxicity in plants. Plant Cell Environ. 27, 1405-1414. doi: 10.1111/j.1365-3040.2004.01243.x

Shi, X., Li, B., Qin, G., and Tian, S. (2012). Mechanism of antifungal action of borate against Colletotrichum gloeosporioides related to mitochondrial degradation in spores. Postharvest Biol. Technol. 67, 138-143. doi: 10.1016/j.postharvbio.2012. 01.003

Shi, X.-Q., Li, B.-Q., Qin, G.-Z., and Tian, S.-P. (2011). Antifungal activity and possible mode of action of borate against Colletotrichum gloeosporioides on mango. Plant Dis. 95, 63-69. doi: 10.1094/PDIS-06-10-0437

Smilanick, J. L., Margosan, D. A., Mlikota, F., Usall, J., and Michael, I. F. (1999). Control of citrus green mold by carbonate and bicarbonate salts and the influence of commercial postharvest practices on their efficacy. Plant Dis. 83, 139-145. doi: 10.1094/PDIS.1999.83.2.139

Strong, P., and Robert, I. (2001). "Boric acid and inorganic borate pesticides," in Handbook of Pesticide Toxicology, ed. R. Krieger (Cambridge, MA: Academic Press), 1249.

Thomidis, T., and Exadaktylou, E. (2010). Effect of boron on the development of brown rot (Monilinia laxa) on peaches. Crop Prot. 29, 572-576. doi: 10.1016/j. cropro.2009.12.023

Wu, Z., Yin, X., Bañuelos, G. S., Lin, Z.-Q., Zhu, Z., Liu, Y., et al. (2015). Effect of selenium on control of postharvest gray mold of tomato fruit and the possible mechanisms involved. Front. Microbiol. 6:1441. doi: 10.3389/fmicb.2015.01441

Yaganza, E., Tweddell, R., and Arul, J. (2014). Postharvest application of organic and inorganic salts to control potato (Solanum tuberosum L.) storage soft rot: plant tissue-salt physicochemical interactions. J. Agric. Food Chem. 62, 9223-9231. doi: $10.1021 / \mathrm{jf5} 517863$
Yaganza, E.-S., Rioux, D., Simard, M., Arul, J., and Tweddell, R. J. (2004). Ultrastructural alterations of Erwinia carotovora subsp. atroseptica caused by treatment with aluminum chloride and sodium metabisulfite. Appl. Environ. Microbiol. 70, 6800-6808. doi: 10.1128/AEM.70.11.6800-6808. 2004

Yaganza, E.-S., Tweddell, R. J., and Arul, J. (2009). Physicochemical basis for the inhibitory effects of organic and inorganic salts on the growth of Pectobacterium carotovorum subsp. carotovorum and Pectobacterium atrosepticum. Appl. Environ. Microbiol. 75, 1465-1469. doi: 10.1128/AEM.02447-08

Yang, Z., Cramer, C., and Lacy, G. (1992). Erwinia carotovora subsp. carotovora pectic enzymes: in planta gene activation and roles in soft-rot pathogenesis. Mol. Plant Microbe Interact. 5, 104-112. doi: 10.1094/MPMI5-104

Yilmaz, M. T. (2012). Minimum inhibitory and minimum bactericidal concentrations of boron compounds against several bacterial strains. Turk. J. Med. Sci. 42, 1423-1429. doi: 10.3906/sag-1205-83

Conflict of Interest Statement: The authors declare that the research was conducted in the absence of any commercial or financial relationships that could be construed as a potential conflict of interest.

Copyright $\odot 2017$ Ahmed, Arif and Alvarez. This is an open-access article distributed under the terms of the Creative Commons Attribution License (CC BY). The use, distribution or reproduction in other forums is permitted, provided the original author(s) or licensor are credited and that the original publication in this journal is cited, in accordance with accepted academic practice. No use, distribution or reproduction is permitted which does not comply with these terms. 